\title{
PEMANFAATAN SENI KOLASE SEBAGAI PRODUK KREATIF UNTUK PENGEMBANGAN KARYA PROYEK STUDI MAHASISWA JURUSAN SENI RUPA FBS UNNES
}

\author{
Arif Fiyanto \\ Fakultas Bahasa dan Seni Universitas Negeri Semarang \\ areeffyant@gmail.com
}

\begin{abstract}
Efforts to develop artworks from student study projects at the FBS UNNES Department of Fine Arts which choose collage art are very interesting when applied to tottebag, as a creative product. After going through observations and various considerations, collage artworks that have been worked on as student study projects will be more economically valuable, and become creative products. So that the work can collaborate into handmade products with archipelago images. Because the material used in making these products uses batik patchwork with designs that utilize Indonesian decorative motifs, especially in developing the tourism potential of Semarang. Thus the use of collage art as a creative product for the development of student study project works can be a research that discusses inspirational and innovative methods of development.
\end{abstract}

Keywords: study projects, creative products, collage art

\begin{abstract}
ABSTRAK
Upaya pengembangan karya senil dari proyek studi mahasiswa di Jurusan Seni Rupa FBS UNNES yang memilih seni kolase sangat menarik apabila diterapkan pada tottebag, sebagai produk kreatif. Setelah melalui pengamatan dan berbagai pertimbangan rupa, karya seni kolase yang sudah tergarap sebagai proyek studi mahasiswa akan lebih bernilai ekonomis, dan menjadi produk kreatif. Sehinga karya tersebut dapat berkolaborasi menjadi produk handmade yang bercitra nusantara. Karena bahan yang digunakan dalam pembuatan produk tersebut menggunakan kain perca batik dengan desain yang memanfaatkan motif dekoratif Indonesia khususnya dalam mengembangkan potensi pariwisata kota semarang. Dengan demikian pemanfaatan seni kolase sebagai produk kreatif untuk pengembangan karya proyek studi mahasiswa bisa menjadi sebuah riset yang mewacanakan metode pengembangan inspiratif dan inovatif.
\end{abstract}

Kata Kunci : proyek studi, produk kreatif, seni kolase

\section{PENDAHULUAN}

Ketika ekonomi telah memasuki dunia global, maka persaingan adalah sesuatu yang tidak terelakkan. Konsekuensinya adalah ke -harusan untuk meningkatkan daya saing bangsa melalui bentuk kreativitas. Oleh karena itu, pemerintah telah meluncurkan program stra- tegis sebagai salah satu unggulan untuk mendukung kedigdayaan ekonomi nasional. Program tersebut adalah industri ekonomi kreatif yang diharapkan tercipta produkproduk berkarakter Indonesia sehingga mampu menembus pasar dunia global. Seiring perkembangan ekonomi bangsa, industri kreatif 
sebagai tumpuan baru dalam pembangunan nasional juga mengalami suatu dinamika. Dalam perjalanannya, industri kreatif meskipun baru mulai digalakkan juga mengalami tantangan dan sekaligus harapan yang sangat potensial. Dalam sisi yang lain, dukungan pemerintah terhadap pengembangan ekonomi kreatif dan industri kreatif telah bergulir dan digalakkan terus-menerus. Kebutuhan pasar global akan kebutuhan produk industri seni, desain, dan kriya sangat besar. Berbagai kenyataan tersebut, tampaknya merupakan sebuah area yang sangat strategis untuk benar-benar dibaca, dipersep -si, dan dihayati sehingga kedinamikaan industri kreatif di Indonesia dapat disikapi menjadi lebih ke arah yang positif demi perbaikan kualitas kesejahteraan bangsa Indonesia.

Berkaitan dengan dinamika tersebut, pendidikan seni rupa memiliki peran yang sangat strategis di dalamnya. Penyebabnya adalah kreativitas merupakan jiwa dari seni itu sendiri. Kreativitas merupakan representasi kualitas sumber daya industri kreatif. Sumber daya manusia merupakan peran sentral dalam penciptaan bentuk kreatif. Baik seni rupa, desain dan kriya merupakan media utama mengelola dan mengoptimalkan sesuatu yang lokal menjadi yang optimal. Kekuatan seni,desain, dan kriya benar-benar dapat dioptimalkan baik melalui cara kerja kreatif maupun dengan sistem manajemen yang baik.

Berdasarkan peluang tersebut mahasiswa Jurusan Seni Rupa FBS UNNES yang notabene sebagai seorang calon seniman, desainer dan kriyawan dapat terstimulus dari berbagai apresiasi publik sehingga dapat mengembangkan karya-karya seni, desain, dan kriya yang lebih inovatif sehingga karya mereka akan dapat menjadi produk kreatif unggulan nusantara memajukan komoditi ekonomi menjadi lebih cerah. Secara tidak langsung, jiwa entreprenurship mahasiswa juga dapat bertambah tangguh dalam menapaki masa depan yang lebih dinamis dan berkembang. Berbagai karya seni yang tercipta pada saat mengaktualkan proyek studi, merupakan modal dasar untuk mengKembangkan diri sebagai alumni yang mampu mandiri dan berdikari menghadapi persaingan dunia global.

upaya yang sejalan dengan program ekonomi kreatif pemerintahan saat ini yang merupakan sebuah konsep ekonomi di era 
ekonomi baru yang mengintensifkan informasi dan kreativitas dengan mengandalkan ide dan stock of knowledge dari Sumber Daya Manusia (SDM) sebagai faktor produksi utama dalam kegiatan ekonominya. Kementerian Perdagangan Indonesia menyatakan bahwa Industri kreatif adalah industri yang berasal dari pemanfaatan kreativitas, keterampilan serta bakat individu untuk menciptakan kesejahteraan serta lapangan pekerjaan dengan menghasilkan dan mengeksploitasi daya kreasi dan daya cipta individu tersebut. Departemen Perdagangan Republik Indonesia (2008) merumuskan ekonomi kreatif sebagai upaya pembangunan ekonomi secara berkelanjutan melalui kreativitas dengan iklim perekonomian yang berdaya saing dan memiliki cadangan sumber daya yang terbarukan.(https://silontong.com/2014 /06/16/).

Upaya pengembangan dari salah satu karya proyek studi mahasiswa Jurusan Seni Rupa FBS UNNES yang menggunakan teknik kolase dalam membuat karya seni sangat menarik jika diterapkan pada kaos, tottebag dan sepatu, sebagai produk kreatif. Setelah melalui peng -amatan dan berbagai pertimbang- an rupa, karya dengan teknik kolase yang sudah tergarap sebagai proyek studi mahasiswa akan lebih bernilai ekonomis jika teknik tersebut digunakan untuk membuat produk kreatif. Sehinga karya tersebut dapat berkolaborasi menjadi produk handmade yang bercitra nusantara. Karena bahan yang digunakan dalam pembuatan produk kreatif tersebut menggunakan kain perca batik dengan desain maupun motif dekoratif Indonesia. Dengan demikian pemanfaatan seni kolase sebagai produk kreatif untuk pengembangan karya proyek studi mahasiswa jurusan seni rupa FBS UNNES tersebut dapat menjadi sebuah penelitian yang mewacanakan metode pengembangan inspiratif dan inovatif.

\section{Metode Penelitian}

Penelitian ini bermaksud menjawab permasalahan secara holistik-sistemik dan faktual. Dikatakan holistik-sistemik karena permasalahan yang dikaji dipandang sebagai satuan sistem yang unsurunsurnya saling mengait secara menyeluruh. Karena masalah yang diajukan dalam penelitian ini lebih menekankan pada pengembangan Pemanfaatan Teknik Kolase Sebagai Produk Kreatif Dalam Pengem- 
bangan Karya Proyek Studi Mahasiswa Jurusan Seni Rupa FBS UNNES.

Maka paradigma pendekatan dan strategi penelitian yang sesuai untuk memecahkan permasalahan penelitian adalah penelitian tindakan (action research). Penelitian tindakan ini, satu siklus yang terdiri dari empat langkah yaitu rencana (plan), tindakan (action), pengamatan (observation), evaluasi (evaluation), dan refleksi (reflection). Pelaksanaan action research ini akan dilaksanakan oleh peneliti sendiri, karena selain sebagai peneliti kedudukan peneliti sekaligus sebagai dosen pengampu mata kolase dan mozaik.

Data penelitian ini merupakan jenis data kualitatif deskriptif. Strategi penelitian semacam ini dipandang lebih mampu menangkap berbagai informasi kualitatif dengan kejelasan deskripsi yang teliti dan penuh makna. Sumber datanya langsung dan peneliti sebagai instrumen utamanya (human instrument) (Bogadan dan Biklen, 1982: 27)

Penetapan paradigma penelitian kualitatif ini didasarkan kesesuaian ciri-cirinya yang: (1) menggunakan rancangan penelitian yang luwes, dalam arti memungkinkan penyempurnaan selama proses penelitian, (2) meneliti latar belakang obyek sesuai dengan kondisi yang wajar atau alamiah (natural setting); (3) menyesuaikan diri dengan kenyataan ganda yang dijumpai dalam proses penelitian; dan (4) prosesnya berbentuk siklus yang saling terkait dengan mengandalkan peneliti sebagai instrumen utama.

Kajian penelitian ini difokuskan pada pengembangan Pemanfaatan Teknik Kolase Sebagai Produk Kreatif Dalam Pengembangan Karya Proyek Studi Mahasiswa Jurusan Seni Rupa FBS UNNES. Berkaitan dengan hal tersebut, maka latar penelitian ditentukan secara langsung pada internal (dalam kampus) khususnya di Jurusan Seni Rupa FBS UNNES. Hal ini dimaksudkan, selain untuk memudahkan peneliti dalam mengkaji objek penelitian, juga agar data yang diperoleh tidak menyimpang dari yang semestinya.

Untuk memperoleh data yang diperlukan dalam penelitian ini, cara yang dilakukan adalah:

1. Data yang berkenaan dengan karya kolase mahasiswa dengan maetrial kain perca, dilakukan dengan observasi atau pengamatan secara langsung dan seksama pada teknik. Pen- 
catatan terhadap hasil amatan yang dilakukan, diikuti perekam -an dengan alat perekam berupa kamera foto.

2. Wawancara mendalam (indepth interviewing), dilakukan untuk menjaring data-data dari informan tentang pandangan mereka terhadap Pemanfaatan Teknik Kolase Sebagai Produk Kreatif Dalam pengembangan karya proyek studi mahasiswa Jurusan Seni Rupa FBS UN NES.

3. Angket, digunakan untuk menjaring data dari responden, dalam hal ini mahasiswa terutama yang berkenaan dengan sikap dan pemahaman mereka tentang pemanfaatan teknik kolase dalam pengembangan karya proyek studi mahasiswa Jurusan Seni Rupa FBS UNNES.

4. Studi dokumenter, dilakukan pada dokumen-dokumen yang berkaitan dengan permasalahan penelitian, termasuk di dalamnya penelaahan terhadap sumber pustaka.

Untuk menjamin atau meningkatkan validitas data dalam penelitian ini diupayakan dengan cara yang disebut triangulasi, sebagai cara yang paling umum digunakan dalam penelitian kualitatif. Triangulasi yang digunakan adalah pengum -pulan data yang menurut Patton dalam Soetopo (1987), yaitu penelitian dengan menggunakan berbagai sumber data yang berbeda untuk mengumpulkan data sejenis atau sama.

Penelitian ini menggunakan tiga komponen analisis, yaitu reduksi data, sajian data, dan penarikan kesimpulan. Proses analisis data dilakukan sejak awal bersama proses pengumpulan data. Proses analisis data dilakukan secara terus menerus dan berkelanjutan selama masa penelitian. Reduksi data merupakan satu bentuk analisis untuk mempertegas, memperpendek, membuat fokus, membuang yang tidak penting guna mengatur data sedemikian rupa. Sajian data merupakan suatu rakitan, susunan, atau pengorganisasian data informasi agar teratur dan mudah dimengerti.

Penarikan kesimpulan adalah langkah terakhir dari dua rangkaian langkah di atas, Jika dalam reduksi data dan sajian data telah diuji validitasnya maka kesimpulan yang di dapat juga semakin kokoh. Penarikan kesimpulan dan verifikasi dilakukan untuk memberi kesimpulan yang cukup mantap dan benar- 
benar bisa dipertanggungjawabkan. Langkah selanjutnya dari penarikan kesimpulan ditindak lanjuti dengan pembuatan model/desain produk, tote bag. Desain dibuat lebih dari satu atau membuat beberapa desain alternatif, dari beberapa desain yang ada selanjutnya di pilih yang terbaik untuk di produksi. Selanjutnya teknik kolase di aplikasikan tote bag.

\section{PEMBAHASAN}

Kata kolase, yang dalam bahasa Inggris disebut (collage), berasal dari kata (coller) dalam bahasa Perancis yang berarti merekatkan. Selanjutnya kolase dipahami sebagai sebuah teknik seni menempel berbagai macam materi selain cat, seperti kertas, kain, kaca, logam, dan lain sebagainya, atau dikombinasikan dengan penggunaan cat atau teknik lainnya (Susanto, M., 2006:63). Seperti yang dijelaskan dalam Sunar-yo (2006) bahwa kolase adalah teknik dalam berkarya seni dengan cara merekatkan atau menempelkan serpihan bahan - bahan limbah atau barang bekas.

Kolase adalah sebuah teknik menempel berbagai macam unsur ke dalam frame sehingga menghasil -kan karya seni yang baru. Dengan demikian, kolase adalah karya seni rupa yang dibuat dengan cara menempelkan bahan apa saja ke dalam satu komposisi yang serasi sehingga menjadi satu kesatuan karya. Kata kunci yang menjadi esensi dari kolase adalah "menempel atau merekatkan" bahan apa saja yang serasi. Karya kolase bisa berwujud sebuah karya utuh atau hanya merupakan bagian dari sebuah karya, misalnya lukisan yang menambahkan unsur tempelan sebagai elemen estetis.

Sebagai karya seni rupa, kolase memiliki susunan unsu-unsur dasar visual. Berbagai unsur rupa yang berbeda karakternya dipadukan dalam suatu komposisi untuk mengekspresikan gagasan artistik atau makna tertentu. Yang dimaksud dengan unsur-unsur rupa disini adalah aspek-aspek bentuk yang terlihat, konkret yang dalam kenyataannya saling terkait dan tak mudah dipisahkan satu dengan lainnya. Tampilan keseluruhannya menentukan perwujudan dan makna aspek bentuk itu sendiri.Unsur unsur rupa (lihat, Susanto, 2011) yang terdapat pada kolase, antara lain: titik dan bintik, garis, bidang, warna, gelap - terang, dan tekstur.

$$
\text { Nilai - nilai estetis suatu karya }
$$
seni dapat dirasakan melalui bentuk 
yang menarik, memuaskan, atau membangkitkan pengalaman visual tertentu. Sehingga seseorang dalam penyusunan unsur-unsur visual meletakkannya sedemikian rupa dalam bidang datar, memadukan berbagai unsurnya, serta mengkomposisikannya agar mendapatkan hasil yang menarik dan memuaskan. Sesungguhnya seseorang itu telah menggunakan sesuatu yang disebut sebagai prinsip - prinsip komposisi.

Prinsip-prinsip komposisi yaitu cara atau asas dalam mengatur, menata unsur-unsur rupa dan mengkombinasikannya dalam menciptakan bentuk suatu karya sehingga mengandung nilai-nilai estetis dan dapat membangkitkan pengalaman visual yang menarik (Sunaryo 2002:6). Pada umumnya prinsip-prinsip rupa tersebut adalah: (1) kesatuan (unity), (2) keserasian (harmony), (3) irama (rhythm), (4) dominasi (emphasis), (5) keseimbangan (balance), dan (6) kesebandingan (proportion).

Dalam menyusun unsur-unsur visual sehingga menjadi sebuah karya yang bermutu dan berkualitas, dalam pembuatan kolase harus memperhatikan prinsip-prinsip penyusunan unsur atau yang di- sebut prinsip-prinsip desain, antara lain:

\section{Kesatuan}

Kesatuan merupakan unsur yang paling mendasar dalam sebuah karya seni, karena kesatuan adalah tujuan akhir dari prinsipprinsip desain yang lain. Sunaryo (2002: 31) menyatakan bahwa tidak adanya kesatuan dalam satu tatanan mengakibatkan kekacauan, ruwet, atau cerai-berai tak terkoordinasi. Jika semua itu sampai terjadi maka karya yang dihasilkan tidak akan bagus dan mengakibatkan terganggunya keindahan suatu karya.

Menurut Rondhi (2002) kesatuan mengandung arti bahwa unsur-unsur visual harus ditata sedemikian rupa sehingga tampak menyatu sesuai dengan tema tertentu. Jadi dapat disimpulkan bahwa kesatuan adalah isi pokok dari komposisi yakni perpaduan dari penerapan prinsip-prinsip komposisi seperti keserasian, keseimbangan, irama, dominasi, dan kesebandingan.

\section{Keserasian}

Keserasian dalam Sunaryo (2002:32) adalah prinsip yang mempertimbangan keselarasan dan keserasian antar bagian dalam suatu 
keseluruhan sehingga cocok satu dengan yang lain dan terdapat keterpaduan yang tidak saling bertentangan.

Sementara Kartika (2007) mengartikan harmony sebagai keselarasan merupakan "paduan unsur-unsur yang berbeda dekat, jika unsur-unsur rupa dipadu secara berdampingan maka akan timbul kombinasi tertentu dan timbul keserasian". Jadi dengan perkataan lain keserasian dan keselarasan merupakan kecocokan antarbagian yang saling berdampingan dalam suatu keseluruhan karya seni dan tidak ada bagian yang saling berlawanan.

\section{Dominasi}

Dominasi adalah pengaturan peran atau penonjolan bagian atas bagian lainnya dalam suatu keseluruhan. Dengan peran yang menonjol pada suatu bagian maka akan menjadi pusat perhatian (Center of Interest) yang merupakan tekanan karena menjadi bagian yang penting dan diutamakan. Memberi istilah dominasi dapat dipandang sebagai prinsip desain yang mengatur pertalian peran bagian dalam membentuk kesatuan bagian-bagian, karena dengan dominasi sua- tu bagian atau beberapa bagian me -kuasai bagian-bagian yang lain.

\section{Irama}

Irama dalam seni rupa merupakan urutan atau keadaan yang berulang secara teratur dari satu elemen lainnya. Irama merupakan prinsip desain yang berkaitan dengan pengaturan unsur-unsur rupa sehingga dapat membangkitkan kesatuan rasa gerak. Dapat dikatakan pula irama adalah gerak usur-unsur rupa dari satu unsur ke unsur yang lain, baik menyangkut warna, bentuk, bidang dan garis. Irama yang ditimbulkan dalam berkarya seni kolase, lebih mengutamakan pada kekuatan membuat variasi bidang, warna dan komposisi.

\section{Keseimbangan}

Ada tiga jenis keseimbangan, yaitu: (1) simetri yaitu keseimbangan setangkup, keseimbangan simetri merupakan keseimbangan belah dua sama kuat antar sisi (2) asimetri yaitu keseimbangan yang bertentangan dengan keseimbangan simetri, sebab bagian antar sisi kanan dan kiri beratnya tidak sama, akan tetapi nilainya tetap sama oleh karena itu tetap seimbang; (3) radial 
yaitu keseimbangan memusat dan memancar keseimbangan ini terjadi karena dalam pengkomposisian ada unsur yang menjadi pusat dan ada yang memencar pada unsur-unsur lainnya. Bagian-bagian itu tetap seimbang karena unsur yang lain saling bertautan dan berkelanjutan. Elemen-elemen dalam proyek studi ini cenderung disusun dengan keseimbangan simetris karena keseimbangan sama kuat antar sisi.

\section{Kesebandingan}

Kesebandingan merupakan upaya pengaturan yang berkenaan dengan ukuran antara bagian satu dengan lainnya. Pengaturan yang dimaksud bertalian dengan ukuran yaitu besar kecilnya bagian, luas sempitnya bagian, panjang pendeknya bagian, atau tinggi rendahnya bagian adalah persoalan proporsi. Dalam seni rupa prinsip proporsi ini digunakan untuk mempertimbangkan perbandingan bidang kertas atau kanvas dengan objek yang digambar atau dilukis. Prinsip kesebandingan lebih menekankan pada variasi atau keragaman ukuran unsur yang satu dengan unsur yang lain dalam kesatuan yang utuh. (Sunaryo 2002:40) menjelaskan kesebandingan berarti hubungan antar bagian terhadap keseluruhan.
Menurut Muharrar (2013) berbagai jenis kolase baik yang berbentuk dua dimensi dan tiga dimensi umumnya dibuat dengan teknik yang bervariasi seperti: teknik sobek, teknik gunting, teknik potong, teknik rakit, teknik rekat, teknik jahit, teknik ikat dan sebagainya. Dalam membuat kolase dapat memanfaatkan lebih dari satu teknik untuk membuat karya kolase.

Berbagai metode yang dipergunakan untuk membuat kolase antara lain :

a. Tumpang - tindih atau saling tutup (overlapping) merupakan metode kolase dengan cara menyusun kembali potongan kain perca secara tumpang tindih.

b. Penataan ruang (spatial arrange -ment)

c. Repetisi/perulangan (repetition)

d. Komposisi/kombinasi beragam jenis tekstur dari berbagai material.

Produk-produk kreatif yang dimaksud adalah melalui produk $t$ shirt, tote bag, dan sepatu. Pada penelitian ini akan dilakukan pemanfaatan teknik kolase lebih khusus pada produk tote bag. Kenapa dipilih, tote bag sebagai media aplikatifnya? Karena tote bag merupa- 
kan produk fashion yang trendnya masih ramai di pasaran terutama pada kalangan anak muda setingkat SMP, SMA, Mahasiswa. Selain itu produk fashion merupakan salah satu produk yang masuk ke dalam kategori produk ekonomi kreatif, yaitu menempati urutan ke-6 dari 15 jenis-jenis/macam-macam ekonomi kreatif di Indonesia. Produk tote bag merupakan produk-produk yang banyak di cari oleh masyarakat khususnya anak muda sekarang ini. Dengan mengaplikasikan gambar dan pemanfaatan teknik kolase pada produk tote bag yang notabene banyak di pakai oleh masyarakat khususnya generasi muda, dengan tampilan yang menarik, yakni dengan pemakaian warnawarna pop maka diharapkan akan semakin menarik minat masyarakat untuk menggunakan produk tersebut. Alasan lain yaitu masih jarang produk-produk fashion dengan konsep tematik, apalagi dengan tema local culture dirasa masih sangat jarang.

Upaya mencapai target tersebut, maka perlu sebuah penelitian yang dirancang dan ditindaklanjuti dengan program pengembangan. Penelitian ini dikembangkan dengan tahapan yang sitematis menggunakan metode observasi langsung, eksperimen, dan evaluasi. Dari berbagai latar belakang di atas maka sangat perlu dilakukan penelitian mengenai Pemanfaatan Teknik Kolase Sebagai Produk Kreatif Dalam Pengembangan Karya Proyek Studi Mahasiswa Jurusan Seni Rupa FBS UNNES.

\section{Proses Pemanfaatan Seni Kolase} Jurusan Seni Rupa FBS UN NES sebagai program studi penyangga konservasi menuju UN NES bertaraf internasional untuk menghasilkan lulusan yang berkompetensi di bidang seni rupa. Jurusan Senirupa Unnes memiliki 3 program studi yaitu S1 Pendidikan Senirupa, S1 Seni Rupa Murni dan D3 Desain Komunikasi Visual.

Mata kuliah Kolase dan Mozaik merupakan salah satu pilihan yang dapat diambil oleh mahasiswa S1 Pendidikan Senirupa dan S1 Seni Rupa Murni. Sedangkan untuk mahasiswa D3 Desain Komunikasi Visual tidak diajarkan sebab program studi ini lebih di fokuskan pada teknik olah visual secara digital. Selama satu semester mahasiswa diberi tugas-tugas dalam rangka latihan memahami seni kolase dan mozaik. Ada tujuh tugas dalam satu semester yang dikerjakan, dan masing-masing tugas dikerjakan 
dalam dua kali pertemuan. Tema yang ditawarkan dalam tugas atau latihan setiap pertemuan bervariatif, begitu pula dengan bahan yang digunakan juga berbada. Diantaranya ada kolase dengan berbahan dasar limbah kertas, limbah kain, limpah plastik dan ada pula yang berbahan organik seperti biji-bijian, dedaunan bahkan ranting-ranting pohon juga di gunakan sebagai bahan dasar pembuatan karya kolase. Masing-masing tugas tersebut dibuat pada papan triplek berukuran variatif, ada yang dibuat berukuran $70 \mathrm{~cm} \times 50 \mathrm{~cm}, 50 \mathrm{~cm} \times 60 \mathrm{~cm}$, dan $50 \mathrm{~cm} \times 50 \mathrm{~cm}$.

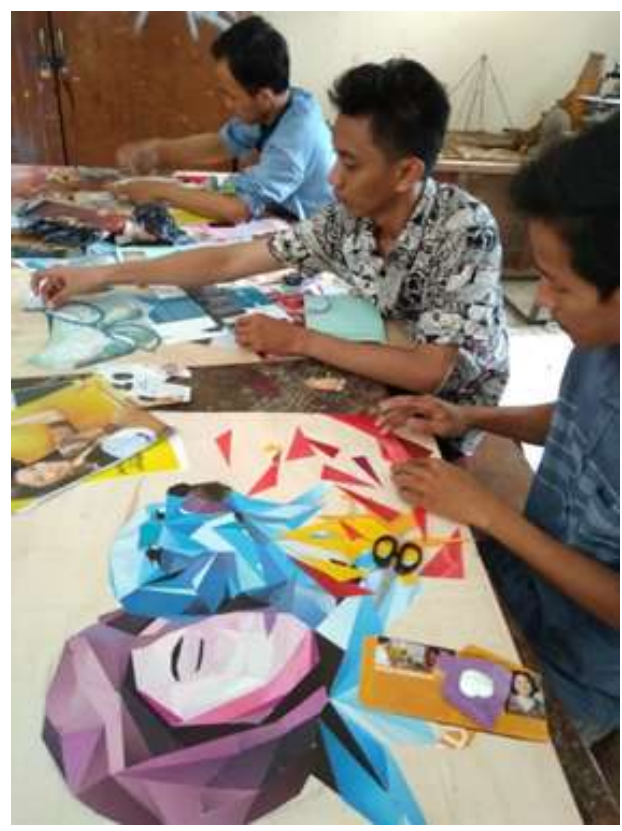

Gambar 01.

Kegiatan Mahasiswa berkarya kolase dalam kelas.

(Foto:Arif Fiyanto, 2018)
Kemudian sebagai nilai ujian semesternya, seluruh mahasiswa membuat even pameran bersama dari karya-karya tugas kolase yang dikerjakan dalam satu semester. Beberapa karya tugas yang diikutkan dalam pameran adalah karyakarya terpilih. Dengan demikian ada proses seleksi yang menentukan nilai pada masing-masing mahasiswa. Semakin banyak yang dipilih karya kolasenya untuk dipamerkan, tentunya berpengaruh dengan nilai yang didapatkan.

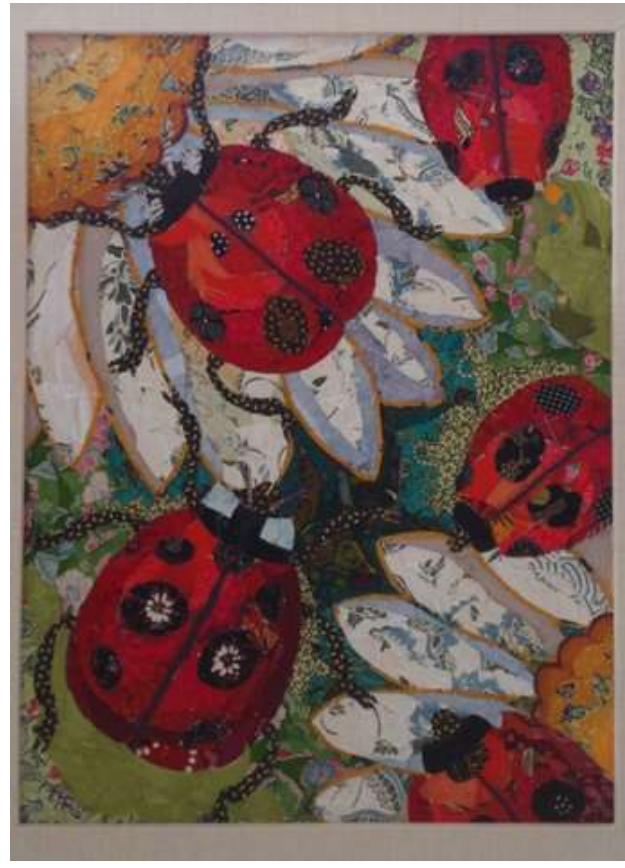

Gambar 02.

Karya kolase mahasiswa sebagai proyek studi

(Foto:Arif Fiyanto, 2018)

Matakuliah kolase dan mozaik belakangan ini peminatnya semakin 
banyak. Meskipun mata kuliah ini menjadi pilihan namun kuota dari mahasiswa yang mengambil semakin banyak. Bahkan ada pula mahasiswa yang memilih membuat karya-karya kolase sebagi proyek studi dalam rangka tugas akhirnya. Dengan tema dan latar belakang yang spesifik membuat karya-karya kolase, dengan menggunakan satu bahan dasar seperti limbah kain dalam proses penciptaan karyanya.

Karya kolase tersebut pada gambar (02) adalah salah satu sampel diantara beberapa karya kolase yang diciptakan oleh mahasiwa sebagai proyek studi. Dengan mengambil tema binatang serangga sebagai pendekatan visual di dalam karya-karya kolasenya menjadi suatu pilihan yang menarik. Ada 10 karya seni kolase yang dibuat untuk proyek studi dengan tema sama. Bahan dasar yang digunakan adalah limbah kain. Pemanfaatan limbah kain yang digunakan untuk membuat karya seni kolase menjadi nilai lebih dalam penilaian.

Berdasarkan apresiasi karya proyek studi mahasiswa yang telah berhasil di pamerkan, muncul inspirasi untuk memanfaatkan seni kolase dengan tema-tema local culture pada totebag sebagai upaya membuat produk kreatif. Dengan memanfaatkan limbah kain, baik yang bermotif dan warna diidentifikasi secara khusus sebagai pengganti warna dalam melukis, teknik yang digunakan adalah tempel, tumpuk dan pengkombinasian dalam bentuk yang menarik.

Penelitiaan ini lebih memfokuskan pada pemanfaatan seni kolase pada tottebag sebagai produk kreatif ini, peneliti memberikan kesempatan kepada salah satu mahasiswa untuk melakukan proses mencipta produk terkait. Ada dua tottebag yang telah dikerjakan sebagai sampel dengan pemanfaatan seni kolase dengan tema ikan bandeng dan warak ngendog. Adapun beberapa proses yang telah di lakukan antaralain :

\section{Persiapan}

Persiapan yang dilakukan dalam penerapan seni kolase pada tottebag antara lain yakni meliputi mempersiapkan desain, kemudian Sketsa serta alat dan bahan yang digunakan. Konten yang dipilih sebagai desain pada tottebag mengcu pada tema-tema ikon pariwisata kota semarang. Alasan pemilihan tema tersebut dalam rangka menyelaraskan antara produk penelitian yang nantinya akan di hasilkan dengan visi misi UNNES sebagai 
kampus yang berwawasan konservasi. Oleh sebab itu desain yang dibuat yakni yang sudah banyak dikenal sebagai ikon kota semarang seperti warak ngendog dan ikan bandeng presto yang dikenal pula sebagai oleh-oleh yang khas semarang. Kedua desain yang dipilih dipersiapkan untuk diterapkan pada tottebag. Langkah berikutnya adalah proses sketsa dilakukan pada tottebag berwarna cerah sehingga hasilnya menjadi lebih menarik. Sketsa dilakukan dengan menggunakan pensil warna. Kemudian proses selanjutnya adalah mempersiapkan alat dan bahan yang digunakan antaralain adalah gunting, lem dan kain batik.

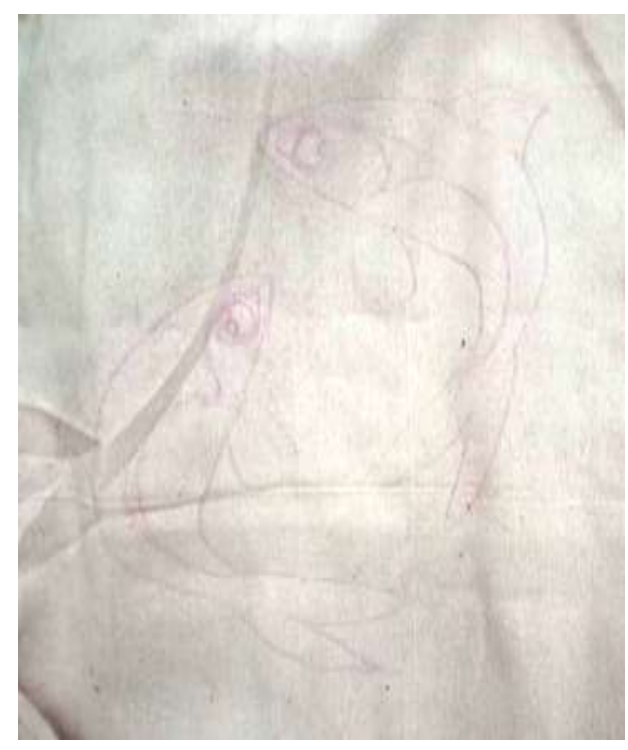

Gambar 03.

Proses sketsa pada Tottebag

(Foto:Arif Fiyanto, 2018)

\section{Proses}

Tahap berikutnya setelah melalui tahap persiapan berlanjut ke proses pembuatan. Pada tahapan ini yang dilakukan antaralain adalah mengidentifaksi warna kain dan motif. Karena yang dimanfaatkan sebagai bahannya adalah kain batik yang memiliki motif dan beragam, dan kain tersebut juga merupakan hasil limbah, maka perlu menyeleksi beberapa potongan kain yang akan dimanfaatkan. Kemudian beberapa kain batik yang sudah diseleksi ini dipotong sesuai ukuran yang diperlukan.
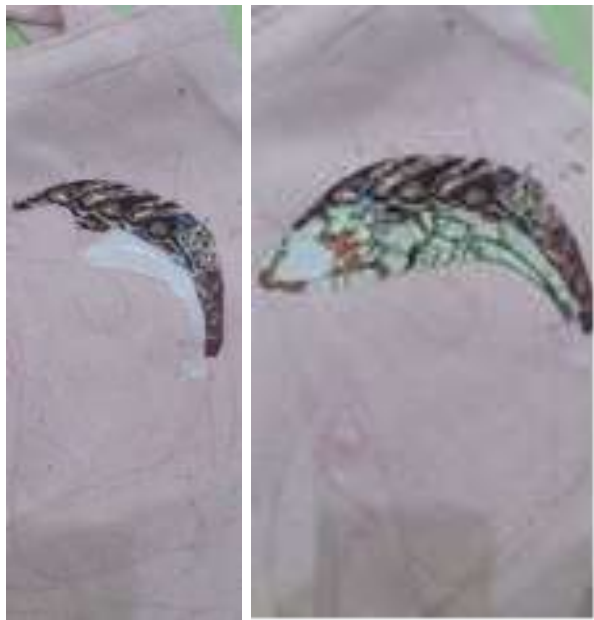

\section{Gambar 04.}

Proses Identifaksi warna kain, meotong, menempel dan menumpuk

(Foto:Arif Fiyanto, 2018)

$$
\text { Setelah potongan - potongan }
$$
kain tersebut sudah sesuai dengan rancangannya proses selanjutnya adalah menempelkannya sesuai 
sket yang telah dipersiapkan pada tottebag. terkait dengan sketsa bentuk yang telah dipersiapkan, dan agar lebih menarik dalam menempel perlu pula menempel dan sekaligus menumpuk kain dengan mo -tif dan warna yang berbeda.

\section{Finishing}

Pada tahapan finishing ini, merupakan tahapan terakhir yang dilakukan untuk memperkuat rekatan dari desain yang sudah diterapkan dengan pemanfaatan seni kolase pada totte bag tersebut.

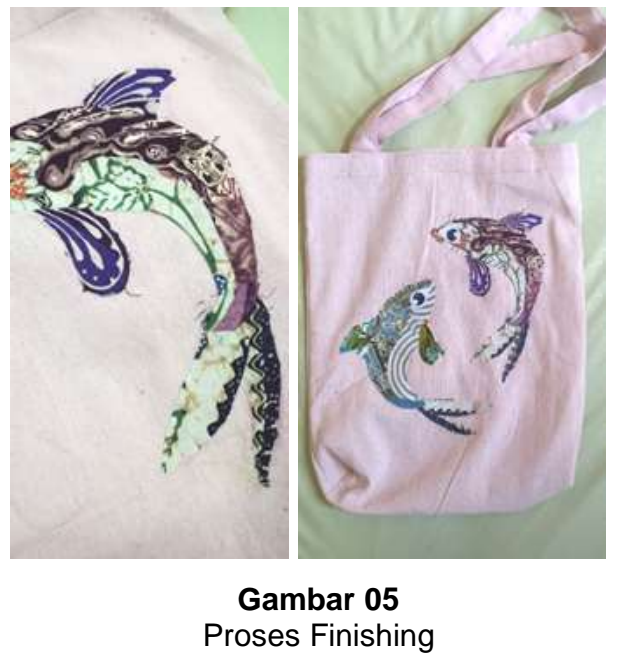

(Foto:Arif Fiyanto, 2018)

Setelah proses selesai dan sudah sesuai dengan desain yang di rencanakan, kemudian hasil nya di oleskan cairan clear dengan menggunakan kuas menyesuaikan ben -tuknya. Selain untuk memperkuat daya kerekatannya, fungsi dari clear ini adalah memberi kesan sedikit mengkilap sehingga hasil yang dilihat menjadi lebih menarik.

\section{SIMPULAN}

Pengembangan dari salah satu matakuliah yang diajarakan pada mahasiswa Jurusan Seni Rupa FBS UNNES, dan kemudian memilih seni kolase sebagai proyek studi dalam rangka menyelesaikan Tugas Akhir, ternyata sangat menarik apabila diterapkan pada tottebag sebagai produk kreatif. Setelah melalui pengamatan dengan berbagai pertimbangan rupa, kemudian dilakukan proses pemanfaatan karya seni kolase menjadi lebih bernilai ekonomis apabila diterapkan pada produk kreatif. Sehinga karya tersebut dapat berkolaborasi menjadi produk handmade. Konten yang dipilih sebagai desain pada tottebag mengcu pada tema-tema ikon pariwisata kota semarang. Alasan pemilihan tema tersebut dalam rangka menyelaraskan antara produk penelitian yang di hasilkan dengan visi misi UNNES sebagai kampus yang berwawasan konservasi. Dengan demikian proses pemanfaatan seni kolase pada totte bag ini telah berhasil dibuat dan 
merupakan produk kreatif yang siap bersaing di pasar baik nasional maupun internasional. Dan menjadi rencana kedepan, tentu akan dilakukan penelitian lebih jauh tentang inovatitas produk kreatif dengan pemanfaatan seni kolase baik secara tampilan bentuk maupun penerapannya pada produk yang lain.

\section{DAFTAR PUSTAKA}

Bogdan, Robert, S. \& Biklen, Qua litative Research for Educa tion: An Introduction to Theory and Methods, Boston: Allyn and Bacon, Inc, 1982.

Muharrar, Syakir dan Sri Verayanti. 2013. Kreasi Kolase, Mon tase, Mozaik Sederhana. Se marang: Erlangga

HB. Sutopo, Metodologi Penelitian Kualitatif, Surakarta: Universi tas Sebelas Maret Press, 2006

Rondhi, Moh. 2002. Tinjauan Seni Rupa 1. Semarang: Universi tas Negeri Semarang.

Rondhi, Moh dan Anton Sumartono. 2002. Paparan Perkuliahan mahasiswa: Tinjauan Seni Ru pa I. Semarang: Unnes Press.

Sunaryo, Aryo. 2002. Paparan Per kuliahan Mahasiswa Nirmana 1. Semarang. Jurusan Seni Rupa Unnes.
Sunaryo, Aryo. 2010. MOZAIK: Menata Kepingan, Menjadi Karya Menarik. Yogyakarta: Pusat Perbukuan Departemen Pendidikan Nasional.

Susanto, Mikke. 2002. Diksi Rupa: Kumpulan Istilah Seni Rupa. Yogyakarta: Kanisius.

Susanto, Mikke. 2012. Diksi Rupa: Kumpulan Istilah dan Gerakan Seni Rupa. Yogyakarta: Dicti Art Lab. 